\title{
Powder and Solvent for Endocervical Gel Dosage Form
}

National Cancer Institute

\section{Source}

National Cancer Institute. Powder and Solvent for Endocervical Gel Dosage Form. NCI Thesaurus. Code C149780.

Powder and solvent intended for the preparation of an endocervical gel by mixing the powder and the solvent. 